\title{
The leaf-feeding beetle, Cassida rubiginosa, has no impact on Carduus pycnocephalus (slender winged thistle) regardless of physical constraints on plant growth
}

\author{
Jonty Mills, Sarah Jackman, Chikako van Koten, and Michael Cripps* \\ AgResearch, Lincoln Science Centre, Private Bag 4749, Lincoln, New Zealand \\ *Corresponding author: mike.cripps@agresearch.co.nz \\ (Original submission received 4 September 2020; accepted in revised form 15 November 2020)
}

\begin{abstract}
The leaf-feeding beetle, Cassida rubiginosa, is an oligophagous biocontrol agent capable of feeding on most species in the tribe Cardueae (thistles and knapweeds). The beetle was released in New Zealand in 2007, primarily to control Cirsium arvense (Californian thistle), with the recognition that it had potential to control multiple thistle weeds. The objective of this study was to test the impact of different densities of Cassida rubiginosa larvae $(0,50,100$, or 200 per plant) on the growth and reproductive performance of the annual thistle weed, Carduus pycnocephalus (slender winged thistle). Since the effectiveness of biocontrol agents is often enhanced when plants are stressed, different levels of growth constraint were imposed by growing the weed in different pot sizes $(0.5,1,5$, and 12 litres). We hypothesised that feeding damage by Cassida rubiginosa larvae would have a greater impact on the weed when grown in smaller pots, since root growth would be constrained, and the weed's ability to compensate for feeding damage would be restricted. Contrary to our hypothesis, pot size had no effect on feeding damage by Cassida rubiginosa on Carduus pycnocephalus. As expected, most measures of plant performance increased with larger pot sizes, including plant height, biomass, and the number of seedheads per plant. The results of this study indicate that Cassida rubiginosa is unlikely to contribute to the control of Carduus pycnocephalus. Additional oligophagous biocontrol agents targeting the rosette stage and seed production should be considered for release in New Zealand.
\end{abstract}

Keywords folivory, herbivory, pot size, plant stress, thistle

\section{INTRODUCTION}

The leaf-feeding beetle, Cassida rubiginosa Müller (Coleoptera: Chrysomelidae), was released in New Zealand in 2007 as part of the biocontrol programme against the pasture weed, Cirsium arvense (L.) Scop. (Asterales: Asteraceae) (Californian thistle) (Cripps et al. 2011). Prior to release of the beetle, several studies demonstrated that it had potential to be a successful biocontrol agent by reducing the growth and biomass of Cirsium arvense (Ang et al. 1995; Bacher \& Schwab 2000; Cripps et al. 2010). Further evaluation in New Zealand indicated that under typical sheep-grazed pasture management, the beetle was able to reduce the density and local spread of Cirsium arvense, where competition from forage plants, and dry conditions, likely contributed to its effectiveness (Cripps et al. 2019). Cirsium arvense is a perennial weed that spreads and reproduces vegetatively by creeping lateral roots (separation of clonal ramets). In established pasture, there is generally little population recruitment from seed unless there is disturbance (e.g. from livestock or tillage) (Edwards et al. 2000). Therefore, management of Cirsium arvense in pasture is focused on reducing vegetative growth of the weed by exhausting the root reserves through repeated defoliation tactics such as mowing, herbicides, or herbivory by biocontrol agents. The impact of Cassida rubiginosa on Cirsium arvense is through defoliation that reduces the leaf area duration of the weed (Bourdôt et al. 1998; Bourdôt et al. 2016). Both the adults and larvae feed on the leaves from spring until autumn (October to March) and, at high population densities, the beetle can consume all green leaf tissue, causing a 'skeletonising' effect on the weed (Cripps 2013). Reduced leaf area over the growing season results in less root production and, subsequently, reduced thistle shoot density the following season (Donald 1993; Cripps et al. 2019).

While Cirsium arvense is the primary target weed, the beetle is oligophagous, and can feed on most species in the tribe Cardueae (thistles and knapweeds) (Zwölfer \& Eichhorn 1966), many of which are current or potential weed species in New Zealand (Cripps et al. 2013). Since there are no native Cardueae species in New Zealand (Webb et al. 1988), and few economically valued plants in the tribe (e.g. artichoke and safflower), the broad host-range of the agent was considered safe, with the additional benefit of potentially controlling multiple thistle weeds (Bourdôt et al. 2007; Cripps et al. 2013). In contrast to Cirsium arvense, all 
other thistle weeds reproduce solely by seed; therefore, the beetle must prevent or reduce seed production in order to be effective against these other thistle weeds. Furthermore, although most thistle species are host plants, the survival rates of Cassida rubiginosa larvae decrease with increasing phylogenetic distance from the primary host, Cirsium arvense. Thus, the weeds with greatest potential to be controlled by the beetle are close relatives of Cirsium arvense, primarily Cirsium and Carduus species, where survival rates of the larvae are high (Cripps et al. 2016).

Based on this finding, the impact of Cassida rubiginosa was tested on the closely related biennial thistle, Cirsium palustre (L.) Scop. (marsh thistle) at a range of larval densities $(0,50,100$, and 200 per plant) (Hettiarachchi et al. 2018). Despite high levels of feeding damage (60 to $70 \%$ defoliation) the beetle had no effect on plant size or reproductive output (number of seedheads and seeds produced). The authors noted the weed was grown in large pots (12 litre) with plenty of space, nutrients, and water, which may have enabled the plants to compensate for the damage caused by larvae feeding. The beetle might be more effective if the plants were grown under more natural conditions where they must compete for limited space and resources (Hettiarachchi et al. 2018).

To test if Cassida rubiginosa might have an impact on the growth of other Cardueae species under constrained growth conditions, we conducted a similar experiment with the annual thistle weed, Carduus pycnocephalus L. (slender winged thistle). Carduus pycnocephalus is a common pasture weed, often forming dense patches, resulting in reduced pasture productivity, particularly in the drier east coast regions of both the North and South islands of New Zealand (Kelly \& Popay 1985; Popay et al. 2010). The objective of this study was to test the impact of different densities of Cassida rubiginosa larvae on the growth and reproductive performance of Carduus pycnocephalus. A $4 \times 4$ factorial experiment was established to test the same larval densities applied to Cirsium palustre, but additionally under four different levels of growth constraint, imposed by different pot sizes $(0.5,1.0,5.0$, and 12 litres). Pot size is well-known to affect plant growth and fitness through multiple mechanisms, notably by constraining root growth, and restricting access to water and nutrients (Poorter et al. 2012). Specifically, we hypothesised that there would be an interaction between pot size and larval density. That is, feeding damage by Cassida rubiginosa larvae would have a greater impact on the weed when grown in small pots, since root growth would be constrained, and the weed's ability to compensate for feeding damage would be restricted.

\section{MATERIALS AND METHODS}

Seeds of Carduus pycnocephalus were sown on 18 September 2019. Seedlings were transplanted into 0.5 litre pots on 9 October and maintained in a glasshouse at AgResearch, Lincoln, New Zealand. On 25 October, the plants were transplanted into their experimental treatment pots, moved to an outdoor enclosure on the campus of AgResearch

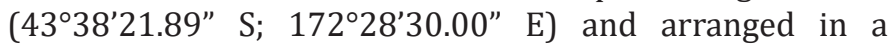
randomised block design. The experiment consisted of two treatment factors, each with four levels: pot size $(0.5,1,5$, and 12 litres) and Cassida rubiginosa larval density $(0,50$, 100, and 200 larvae per plant). There were four replicate blocks of the 16 treatments (64 Carduus pycnocephalus plants in total). The plants were grown in a standard potting mix (54\% aged bark, 45\% sand, 1\% nutrients, by weight) with nutrients included in the potting mix as Osmocote ${ }^{\circledR}$ 17-11-10 (N-P-K), lime, superphosphate, sulphate of potash and calcium nitrate. The plants were watered three times per day through an automatic irrigation system that delivered water directly to the soil in the pots.

A colony of approximately 200 adult Cassida rubiginosa was established from beetles collected in the Lincoln area between 31 October and 7 November 2019. The beetle colony was maintained in a laboratory at AgResearch at a constant temperature $\left(20^{\circ} \mathrm{C}\right)$ in 2 -litre ventilated plastic containers and provided with fresh Cirsium arvense clippings three times weekly. Egg masses were collected from the Cirsium arvense clippings and transferred into Petri dishes lined with moist filter paper. Egg masses collected from 31 October to 11 November were chilled at $10^{\circ} \mathrm{C}$ until 18 November after which they were maintained at $20^{\circ} \mathrm{C}$ in the laboratory to delay hatching and synchronise a larger number of larvae to apply. From 12 November, egg masses collected from shoot clippings were maintained at $20^{\circ} \mathrm{C}$ in the laboratory until first instar larvae hatched. Beginning on 21 November, the appropriate number of naïve first instar larvae for each treatment were applied to the plants. Larval application continued as larvae hatched and was completed on 18 December 2019. Larvae were applied individually to the leaves of the plants one block at a time. The application of larvae took from 4 to 7 days per block to complete. Starting on 3 December 2019, weekly assessments (with exception of 31 December) of larval feeding damage (visual estimate \% leaf area consumed), plant height, and the number of seedheads per plant were conducted. In total, eight assessments were conducted with the final assessment on 28 January 2020, when plants were assessed visually to be in a senescent state (most leaves yellowed or abscised). Larval feeding damage assessments were not taken from 24 plants in a senescent state. On 21 February 2020, the shoots and roots of each plant were harvested. Shoots were cut to the soil surface, dried in a forced air oven at $60^{\circ} \mathrm{C}$, and the dry weights were recorded. Roots were washed, dried at $60^{\circ} \mathrm{C}$, and the dry weights were recorded.

To assess seed production and percentage germination three post-flowering seedheads were collected from each plant on 6 January 2020. The seeds from each individual seedhead were stored in paper envelopes at $20^{\circ} \mathrm{C}$. The germination test was established as a $4 \times 4$ Latin square design to account for possible differences within the incubator and consisted of four replicate blocks $(16$ treatments $\times 3$ seed categories $\times 4$ replicates $=$ 192 seed bags in total). Carduus pycnocephalus has two morphologically and functionally distinct seed types: inner and outer seeds. The inner seeds are a light cream colour, striated, covered in a sticky mucilage, and have a well-developed pappus for dispersal. The outer seeds have a darker colour, are smooth, not sticky, and have only a vestigial pappus. The outer seeds typically remain in 
the seedhead even after its abscission, whereas the inner seeds (in the centre of the seedhead), are more easily wind dispersed (Olivieri et al. 1983). The seeds from each seedhead were sorted into three categories: inner, outer, and underdeveloped. Seeds were classified as 'underdeveloped' if they appeared smaller than the inner and outer seeds, shrivelled, and light to dark brown in colour. On 29 January, the number of seeds in each seedhead in each category were counted. The seeds from each plant (three seedheads per plant) were pooled by category, and the average seed weight per category was recorded to nearest $0.1 \mathrm{mg}$. A subsample of 10 seeds were weighed for each category, unless there were less than 10 seeds in total, in which case all were weighed.

The proportion of seed that germinated (\%) was determined for each category of seed from each combination of treatment factors (pot size and larval density). Seeds were pooled across the four replicate plants for each treatment combination creating 16 packages of each seed category. A subsample of 10 seeds were tested for each category, unless there were less than 10 seeds in total, in which case all available seed was used. The seeds were placed on moistened paper towel which was placed inside a sealed plastic bag $(62 \times 75 \mathrm{~mm})$. These were placed in an incubator on 5 February 2020 set to conditions previously reported as the optimum for germination of Carduus pycnocephalus (constant $15^{\circ} \mathrm{C}$ with a 12 -hr photoperiod) (Olivieri et al. 1983). Germination was recorded after 20 days in the incubator, allowing sufficient time for both inner and outer seed types to germinate (Olivieri et al. 1983). Seeds were considered to have germinated if the radicle had protruded $(>2 \mathrm{~mm})$ out of the seed coat.

\section{Statistical analyses}

The last data recorded for \% leaf area consumed on 21 January were analysed using two-way analysis of variance (ANOVA) with pot size and larval density as factors. Block effects were excluded since observations were unbalanced among blocks since damage assessments were not taken from plants in a senescent state. Prior to the ANOVA, the $\%$ leaf area consumed values were $\log _{\mathrm{e}}(\mathrm{x}+1)$-transformed to stabilise the variance. Adding a value of one was required to include observed zero damage values in the analysis. Final plant height (as measured on 28 January) was also analysed using two-way ANOVA. Block effects were not included due to their non-significance.

The final data collected on 28 January for seedheads per plant were over-dispersed counts (counts showing dispersion larger than Poisson distributions) so were analysed using a generalised linear model (GLM) with negative binomial distributions through a log link function. The GLM tested effects of larval density and pot size factors for comparison, and block effects for blocking.

The number of seeds per seedhead was analysed using three-way ANOVA, testing the effects of pot size, larval density, and seed type. Block effects were not included due to their non-significance. Since the number of seeds per seedhead was not over-dispersed and its distribution was approximately normal, the ANOVA was considered more appropriate than a GLM analysis. Seed weight was also analysed using the three-way ANOVA, after being $\log _{\mathrm{e}}$-transformed to stabilise the variance. Block effects were not applicable for seed weights as the number of seeds measured was not balanced among blocks, due to some plants among blocks not having produced any seed for some seed types.

Percentage germination of sampled seeds was analysed using a GLM with binomial distributions through a logit link function. This GLM tested the main effects of pot size, larval density, and seed type, without any interaction. Inclusion of any interaction term was inappropriate since some factorial level combinations resulted in groups with no germination at all.

Shoot and root dry weights of plants (harvested on 21 February) were analysed using two-way ANOVA with pot size and larval density as factors. Prior to the ANOVAs, both weight values were $\log _{\mathrm{e}}$-transformed to stabilise the variance.

For all ANOVAs, pair-wise comparisons between the factor levels were made using Fisher's LSD (5\%) method. In the GLM analysis, pair-wise factor-level comparisons were made using a $Z$ statistic, which was calculated from the difference of compared means. All statistical analyses were carried out with SAS version 9.4 (SAS Institute Inc. 2012).

\section{RESULTS}

Feeding damage by Cassida rubiginosa larvae increased over time (Fig. 1). The larval density treatments resulted in significant differences in final percentage feeding damage $\left(\mathrm{F}_{3,33}=25.47 ; \mathrm{P}<0.001\right)$. The final percentage feeding damage was greatest in the 200 larval density treatment $(49.4 \% \pm$ 8.7), but there was no significant difference between the 50 and 100 larval density treatments $(23.5 \% \pm 6.8 \%$ and $15.6 \% \pm 2.0 \%$, respectively) (Fig. 1). All beetle treatment

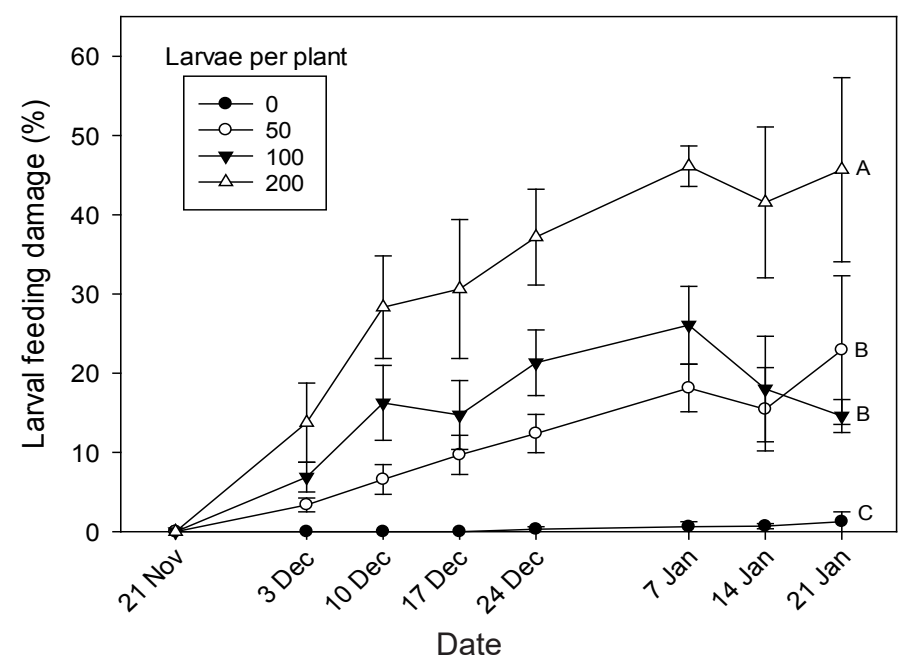

Figure 1 Mean $( \pm$ SE) feeding damage (\% leaf tissue consumed averaged over pot size) by larvae of Cassida rubiginosa for the four larval density (number of larvae per plant) treatments at each assessment time point. For the final damage assessment time (21 January), means with different letters indicate significant differences (LSD 5\%). Statistical inferences are based on $\log _{\mathrm{e}}(\mathrm{x}+1)$-transformed values. 
groups had significantly greater feeding damage than the control group where no larvae were applied. Trace levels of feeding damage $(1.0 \% \pm 0.7 \%)$ were detected in the control group due to adult beetle feeding from the resident Cassida rubiginosa population (Fig. 1). There was no effect of pot size on the final percent feeding damage $\left(\mathrm{F}_{3,33}=0.76\right.$; $\mathrm{P}=0.525)$, and no interaction between pot size and larval density $\left(\mathrm{F}_{9,24}=0.36 ; \mathrm{P}=0.944\right)$.

Final plant height was significantly affected by pot size $\left(\mathrm{F}_{3,57}=8.46 ; \mathrm{df}=3 ; \mathrm{P}<0.001\right)$, but there was no effect of larval density treatments $\left(\mathrm{F}_{3,57}=0.32 ; \mathrm{P}=0.814\right)$, and no interaction $\left(F_{9,48}=0.84 ; P=0.580\right.$; Fig. 2$)$. The number of seedheads per plant increased over time for all treatments (Fig. 3). There was a significant effect of pot size on the final number of seedheads per plant counted on 28 January $\left(\chi^{2}=1175.31\right.$; $\mathrm{df}=3 ; \mathrm{P}<0.0001)$, and pair-wise comparisons indicated significant differences between all four pot sizes (Fig. 3a). There was no significant effect of larval density on the final number of seedheads per plant $\left(\chi^{2}=4.06\right.$; $\mathrm{df}=3$; $\mathrm{P}=0.255$; Fig. $3 \mathrm{~b}$ ), and no interaction between pot size and larval density $\left(\chi^{2}=7.32 ; \mathrm{df}=9 ; \mathrm{P}=0.604\right)$. The number of seeds per seedhead was not affected by pot size $\left(\mathrm{F}_{3,144}=0.23 ; \mathrm{P}=0.874\right)$ or larval density $\left(\mathrm{F}_{3,144}=0.14 ; \mathrm{P}=0.935\right)$. However, the number of seeds per seedhead differed significantly by seed type $\left(\mathrm{F}_{2,144}=1110.3\right.$; $\left.\mathrm{P}<0.001\right)$, with pair-wise comparisons indicating differences between each of the three seed types (Table 1). There was a significant interaction between pot size and seed type $\left(\mathrm{F}_{6,144}=2.65 ; \mathrm{P}=0.018\right)$, where the number of seeds per seedhead increased with larger pot size for the inner seeds but did not differ for the outer and underdeveloped seeds. There was also a significant threeway interaction $\left(\mathrm{F}_{16,144}=1.84 ; \mathrm{P}=0.025\right)$ indicating that the significant pot size and seed type interaction further differed across larval density treatments (the greatest number of inner seeds per seedhead occurred at low larval densities for 5 - $\mathrm{L}$ pots, and the greatest number of inner seeds per

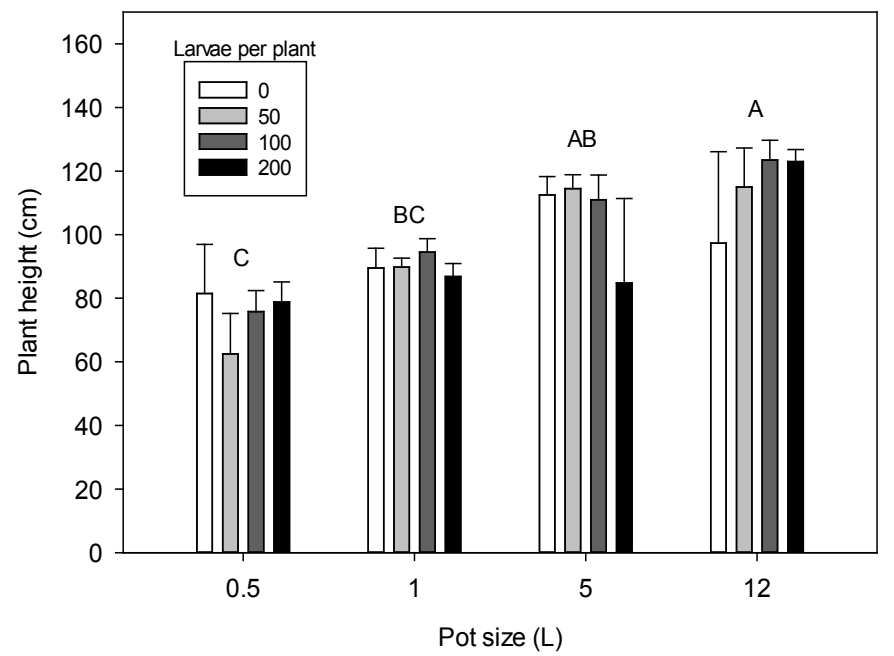

Figure 2 Mean $( \pm \mathrm{SE})$ final height of Carduus pycnocephalus plants grown in four different pot sizes and with four different larval densities of the leaf-feeding beetle, Cassida rubiginosa. Significant differences between the overall mean for pot size groups are indicated by different letters (LSD 5\%). seedhead occurred at high larval densities for 12-L pots).

There was no significant effect of pot size on mean seed weights $\left(\mathrm{F}_{3,173}=1.82\right.$ : $\left.\mathrm{P}=0.145\right)$. There was a significant main effect of larval density on seed weight $\left(\mathrm{F}_{3,173}=7.01\right.$; $\mathrm{P}<0.001$ ), although this did not follow a consistent pattern, with the only significant difference being the weight in the 100 larvae treatment having greater weight than the 0 and 50 larvae treatments. There was a highly significant difference in the mean seed weight between the three seed

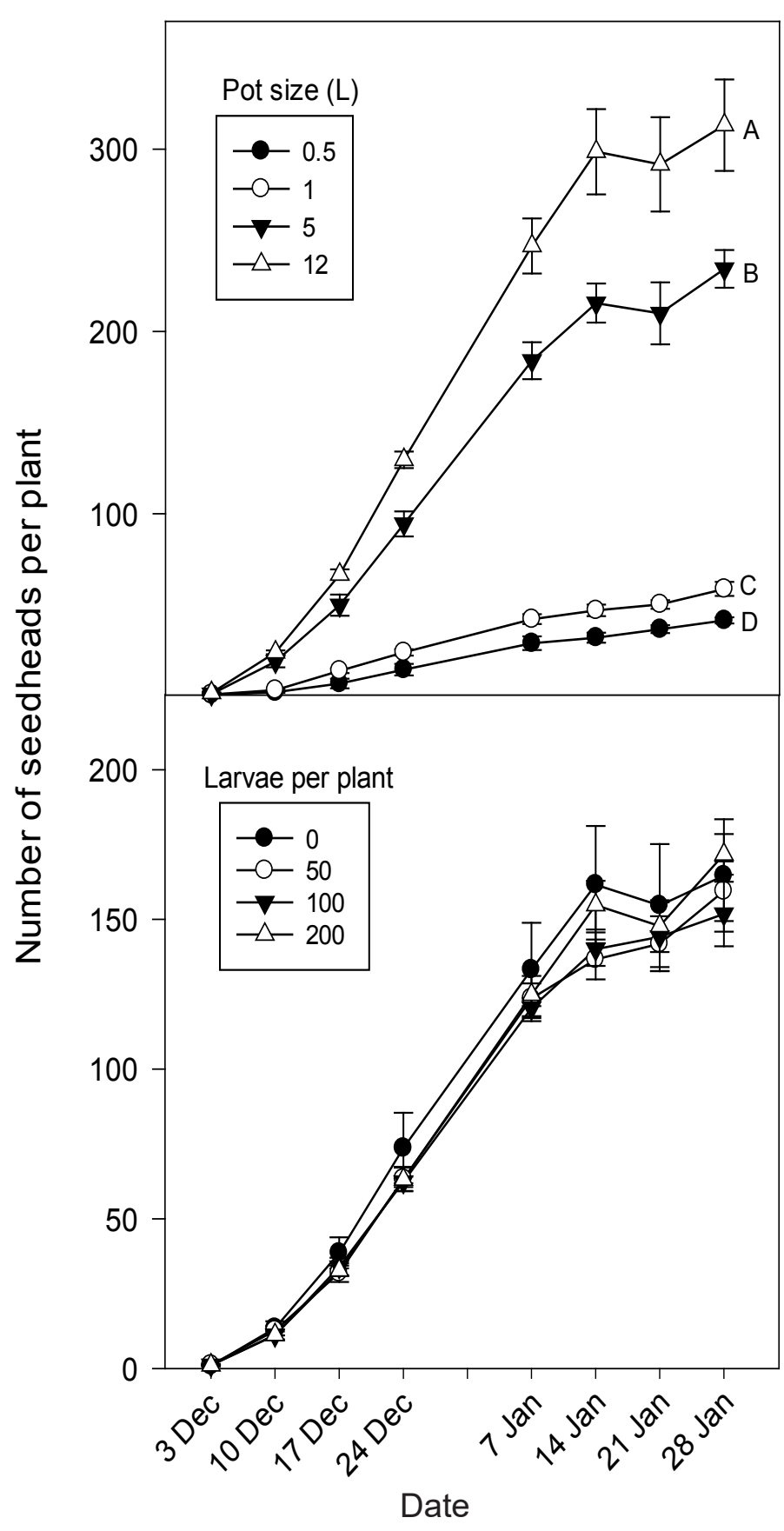

Figure 3 Mean $( \pm$ SE) number of seedheads per plant at each assessment time point for Carduus pycnocephalus grown in the different pot sizes (a) and with different larval densities of Cassida rubiginosa (b). Significant differences between the pot sizes for the mean number of seedheads per plant at the final assessment time (28 January) are indicated with different letters (LSD 5\%). 
Table 1 Mean $( \pm$ SE) number of seeds per seedhead, seed weight, and percentage germination of three seed types (inner, outer and under-developed seeds) of Carduus pycnocephalus (slender winged thistle). Means followed by different letters indicate significant differences between seed types for each variable (LSD 5\%).

\begin{tabular}{llll}
\hline Parameter & \multicolumn{3}{c}{ Seed type } \\
\cline { 2 - 4 } & Inner & Outer & $\begin{array}{c}\text { Under- } \\
\text { developed }\end{array}$ \\
\hline $\begin{array}{l}\text { Number of } \\
\text { seeds per } \\
\text { seedhead }\end{array}$ & $16.5 \pm 0.38 \mathrm{a}$ & $1.1 \pm 0.09 \mathrm{c}$ & $2.5 \pm 0.23 \mathrm{~b}$ \\
$\begin{array}{l}\text { Seed weight } \\
\text { (mg) }\end{array}$ & $5.72 \pm 0.17 \mathrm{a}$ & $4.66 \pm 0.50 \mathrm{~b}$ & $1.22 \pm 0.05 \mathrm{c}$ \\
$\begin{array}{l}\text { Germination } \\
(\%)\end{array}$ & $49.7 \pm 3.1 \mathrm{a}$ & $41.6 \pm 3.7 \mathrm{~b}$ & $0.0 \mathrm{c}$ \\
\hline
\end{tabular}

types $\left(\mathrm{F}_{2,173}=348.74 ; \mathrm{P}<0.001\right)$, with pair-wise comparisons indicating significant differences between all three types (Table 1). There were no significant interactions between pot size, larval density, or seed type on mean seed weight $(\mathrm{P} \geq 0.159)$.

Both larval density $\left(\chi^{2}=19.06 ; \mathrm{df}=3 ; \mathrm{P}<0.001\right)$ and pot size had a significant effect on the overall average percentage of seed germination (Table 2). Seed type also had a significant effect on the overall average percentage germination $\left(\chi^{2}=10.77, \mathrm{df}=1, \mathrm{P}=0.001\right)$, with pair-wise comparisons indicating differences between all three seed types (Table 1). None of the underdeveloped seed germinated (Table 1).

There was a significant effect of pot size on harvested shoot dry weights $\left(\mathrm{F}_{3,57}=339.2 ; \mathrm{P}<0.001\right)$, but no effect of larval density treatment $\left(\mathrm{F}_{3,57}=1.76 ; \mathrm{P}=0.165\right)$, and no interaction between pot size and feeding damage $\left(\mathrm{F}_{9,48}=0.51\right.$; $\mathrm{P}=0.863$ ). Similarly, there was a significant effect of pot size on harvested root dry weight $\left(\mathrm{F}_{3,57}=48.1 ; \mathrm{P}<0.001\right)$, but no effect of larval density $\left(\mathrm{F}_{3,57}=0.73 ; \mathrm{P}=0.540\right)$, and no interaction $\left(\mathrm{F}_{9,48}=1.17 ; \mathrm{P}=0.336\right)$. Pair-wise comparisons indicated that shoot and root dry weights were greatest in 12 -L pots, followed by 5 -L pots, but not significantly different between 1- and 0.5-L pots (Fig. 4).

Table 2 Mean percentage germination $( \pm \mathrm{SE})$ of Carduus pycnocephalus seed (both inner and outer seed types) compared for the four different levels of the two treatment factors, larval density $(0,50,100$, or 200 Cassida rubiginosa larvae per plant), and pot size (0.5-, 1-, 5-, or 12-litre pots). Within each treatment factor means followed by different letters are significantly different (LSD 5\%).

\begin{tabular}{ccccc}
\hline & \multicolumn{4}{c}{ Larval density (per plant) } \\
\cline { 2 - 4 } & $\mathbf{0}$ & $\mathbf{5 0}$ & $\mathbf{1 0 0}$ & $\mathbf{2 0 0}$ \\
\hline
\end{tabular}

Germination $38.9 \pm 3.4 \mathrm{~b} \quad 52.0 \pm 3.5 \mathrm{a} \quad 56.4 \pm 3.5 \mathrm{a} \quad 39.6 \pm 3.4 \mathrm{~b}$ $(\%)$

\begin{tabular}{lccc}
\multicolumn{4}{c}{ Pot size (L) } \\
\hline 0.5 & 1.0 & 5.0 & 12 \\
\hline
\end{tabular}

\begin{tabular}{lllll}
\hline Germination & $42.0 \pm 3.5 b$ & $20.8 \pm 2.8 c$ & $45.1 \pm 3.3 b$ & $83.0 \pm 2.7 a$
\end{tabular} (\%)

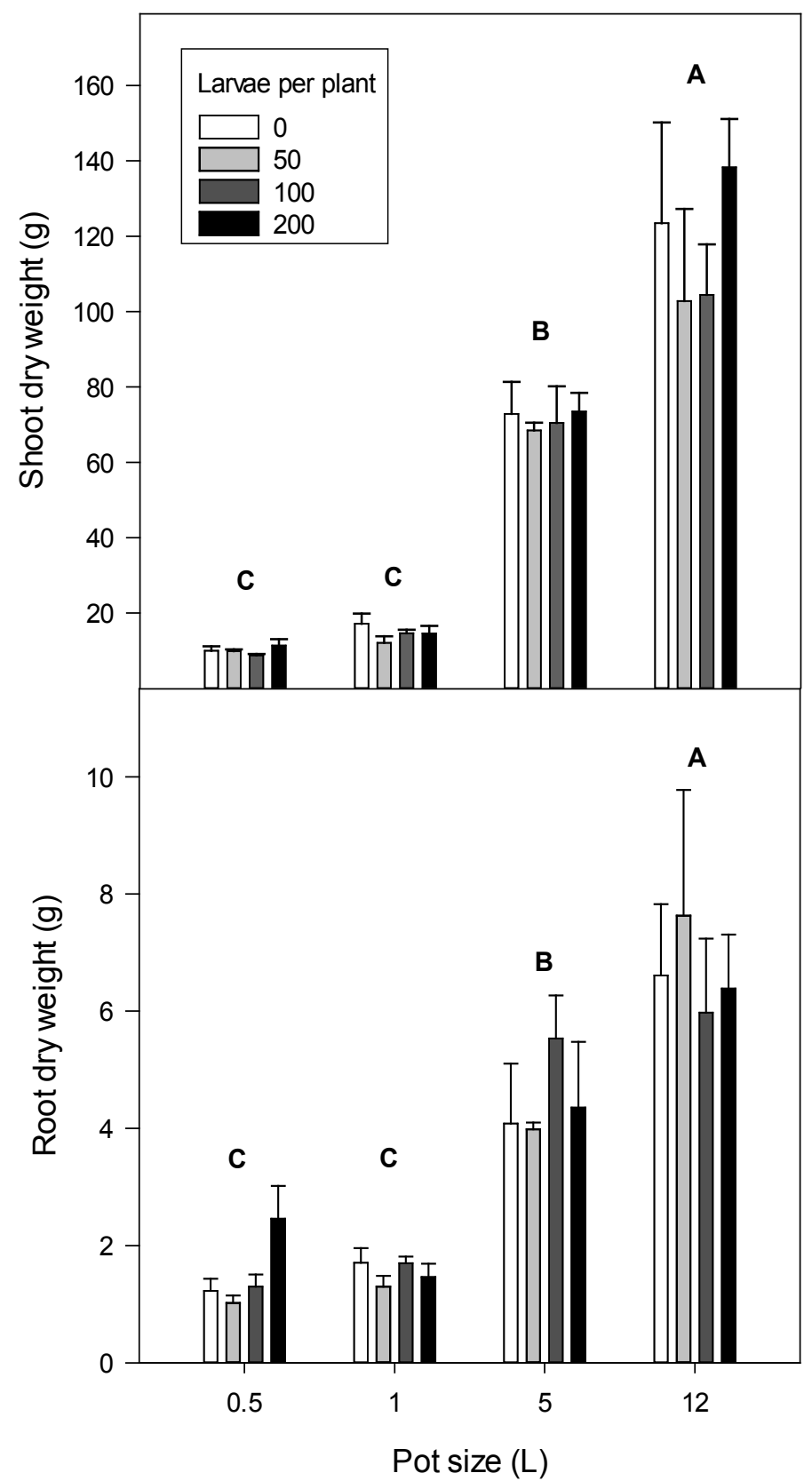

Figure 4 Mean $( \pm S E)$ final shoot $(a)$ and root $(b)$ dry weights of Carduus pycnocephalus grown in four different pot sizes and with four different larval densities of the leaf-feeding beetle, Cassida rubiginosa. Significant differences between the overall mean for pot size groups for the shoot and root dry weights are indicated by different letters (LSD 5\%). Statistical inferences are based on $\log _{\mathrm{e}}$-transformed values.

\section{DISCUSSION}

Overall, feeding damage from larvae of Cassida rubiginosa did not affect the growth (height, or biomass) or reproductive performance (number of seedheads and seeds) of Carduus pycnocephalus.This result was expected based on a previous study where the same larval densities were applied to Cirsium palustre and had no significant impact on the weed (Hettiarachchi et al. 2018). However, we expected that the effect of the beetle would be expressed under the constrained growth conditions imposed by small pot size. Contrary to our hypothesis, the beetle had no effect on plant growth, 
regardless of pot size. The lack of a significant interaction was unexpected since the effectiveness of biocontrol agents is often enhanced when weeds are stressed due to drought (Dhileepan et al. 2000), nutrient deprivation (Burns et al. 2013), or competition from neighbouring plants (Cripps et al. 2010). While pot size directly restricts root growth and consequently aboveground plant biomass, it does not necessarily impose nutrient or drought stress on the plant (Poorter et al. 2012). Therefore, even in small pots, the weed may have had sufficient resources to compensate for the beetle feeding damage.

The maximum feeding damage reached was approximately 50\% defoliation in the highest larval density treatment. This level of feeding damage is lower than the 60 to $70 \%$ defoliation reported for the same larval density (200 per plant) in the experiment with Cirsium palustre (Hettiarachchi et al. 2018) and, therefore, was understandable that it did not have an impact. A similar experiment using Carduus nutans (nodding thistle) reported that $23 \%$ defoliation by larvae of Cassida rubiginosa had no effect on plant growth or seed production (Cartwright \& Kok 1990). In the study with Carduus nutans, it was found that at least $75 \%$ defoliation, imposed by mechanical cutting, was necessary to reduce the growth and reproductive output of the weed. While there was a statistically significant effect of larval density on the percentage seed germination, it did not follow a consistent pattern (the 0 and 200 larvae per plant had reduced germination compared to the 50 and 100 larvae per plant), and there is likely no biological relevance from the impact of feeding damage on the seed germination.

In contrast to the larval density treatments, pot size had a highly significant effect on the performance of Carduus pycnocephalus. As expected, most measures of plant performance increased with increasing pot size, including plant height, biomass, and the number of seedheads per plant (Poorter et al. 2012). There was a pronounced effect of pot size on final plant biomass, with the two largest pot sizes achieving substantially greater biomass than the two smallest pot sizes. Despite a doubling of volume between the 0.5 and 1 litre pots, the size of pots had no significant effect on shoot or root biomass. However, there was a marked increase in shoot and root biomass between the 1 litre and 5 litre pot treatments ( $\mathrm{ca} .5 \mathrm{x}$ and $3 \mathrm{x}$ greater for shoot and root biomass, respectively). From the 5- to 12-litre pot size, there was a significant increase in both shoot and root biomass, although the magnitude of the increase was not as great (ca. 1.5x greater for both shoot and root biomass). In contrast, there was a much weaker effect of pot size on final plant height, which showed a gradual increase with larger pot sizes. For the number of seedheads per plant, the difference between the small ( 0.5 and 1 litre) and large pots ( 5 and 12 litre) was evident after one week, and by the end of the experiment there were differences between all four pot sizes, indicating the reproductive success of the weed is highly influenced by the growth constraint imposed by pot size. The effect of pot size on seed germination did not follow a consistent pattern; however, the percentage germination was substantially greater (nearly double the other pot sizes) in the 12-litre pot size, suggesting that increased plant size may also improve the percentage germination.
From this study on the annual weed, Carduus pycnocephalus, and similar studies on biennial weeds (Cirsium palustre and Carduus nutans), it is evident that Cassida rubiginosa will need to cause a high degree of defoliation to contribute to control of these thistle weeds. Despite many thistle species being classified as biennials, they often survive as a rosette for multiple years, until sufficient size and conditions are met to initiate bolting (Ballegaard \& Warncke 1985; Klinkhamer et al. 1987). For thistle weeds that might remain as rosettes for multiple years, there is greater potential for Cassida rubiginosa, and other biocontrol agents, to have an impact since feeding damage might accumulate over the years. In contrast, annual thistle weeds, such as Carduus pycnocephalus studied here, are unlikely to be affected by leaf-feeding damage from Cassida rubiginosa, since these weeds readily bolt and flower in spring, regardless of the rosette size (Kelly 1988). The results of this study indicate that feeding damage from Cassida rubiginosa is unlikely to contribute to control of annual thistle weeds, even if their growth is constrained. .

In New Zealand, no biocontrol agents have been released specifically for control of Carduus pycnocephalus, or the closely related annual thistle, Carduus tenuiflorus. However, the receptacle weevil, Rhinocyllus conicus, and the rootcrown feeding weevil Trichosirocalus horridus, released against Carduus nutans, are known to attack both Carduus pycnocephalus and Carduus tenuiflorus, although the impact on these weeds is likely minimal (Jessep 1989; Kelly et al. 1990; Groenteman et al. 2008). Biocontrol agents for Carduus pycnocephalus and Carduus tenuiflorus have been released in North America and Australia, with moderate degrees of localised control reported (Groves \& Sheppard 2012; Winston et al. 2014). However, many potential agents were considered unsuitable for release due to their broad Cardueae host ranges (Goeden 1974; Groves \& Sheppard 2012). Since Cardueae-level specialists are considered safe for release in New Zealand (Barratt et al. 2010), as demonstrated in the case of Cassida rubiginosa, additional agents could be considered for release against annual thistle weeds. While the multi-targeting ability of Cassida rubiginosa appears limited, when oligophagous species are considered, there is a much greater pool of agents to select from, and therefore increased potential for successful biocontrol. Successful biocontrol of Carduus pycnocephalus, and other thistle weeds in New Zealand, will likely require case-by-case approaches, where the best agents are selected from the large group of Cardueae specialists.

\section{ACKNOWLEDGEMENTS}

This work was carried out as a summer student internship project financially supported by the AgResearch Strategic Science Investment Fund for Pasture Weed Ecology and Management.

\section{REFERENCES}

Ang BN, Kok LT, Holtzman GI, Wolf DD 1995. Canada thistle (Cirsium arvense (L.) Scop.) response to density of Cassida rubiginosa Müller (Coleoptera: Chrysomelidae) 
and plant competition. Biological Control 5: 31-38. https://doi.org/10.1006/bcon.1995.1004

Bacher S, Schwab F 2000. Effect of herbivore density, timing of attack and plant community on performance of creeping thistle Cirsium arvense (L.) Scop. (Asteraceae). Biocontrol Science and Technology 10: 343-352. https://doi.org/10.1080/09583150050044619

Ballegaard TK, Warncke E 1985. The age distribution of a Cirsium palustre population in a spring area in Jutland, Denmark. Ecography 8: 59-62. https://doi. org/10.1111/j.1600-0587.1985.tb01153.x

Barratt BIP, Howarth FG, Withers TM, Kean JM, Ridley GS 2010. Progress in risk assessment for classical biological control. Biological Control 52: 245-254. https://doi. org/10.1016/j.biocontrol.2009.02.012

Bourdôt GW, Leathwick DM, Hurrell GA, Saville DJ 1998. Relationship between aerial shoot and root biomass in Californian thistle. Proceedings of the New Zealand Plant Protection Society 51: 28-32. https://doi. org/10.30843/nzpp.1998.51.11673

Bourdôt GW, Fowler SV, Edwards GR, Kriticos DJ, Kean JM, Rahman A, Parsons AJ 2007. Pastoral weeds in New Zealand: status and potential solutions. New Zealand Journal of Agricultural Research 50: 139-161. https:// doi.org/10.1080/00288230709510288

Bourdôt GW, Basse B, Cripps MG 2016. Mowing strategies for controlling Cirsium arvense in a permanent pasture in New Zealand compared using a matrix model. Ecology and Evolution 6: 2968-2977. https://doi.org/10.1002/ ece3.2090

Burns EE, Prischmann-Voldseth DA, Gramig GG 2013. Integrated management of Canada thistle (Cirsium arvense) with insect biological control and plant competition under variable soil nutrients. Invasive Plant Science and Management 6: 512-520, 519. https://doi. org/10.1614/IPSM-D-12-00084.1

Cartwright B, Kok LT 1990. Feeding by Cassida rubiginosa (Coleoptera: Chrysomelidae) and the effects of defoliation on growth of musk thistles. Journal of Entomological Science 25: 538-547. https://doi. org/10.18474/0749-8004-25.4.538

Cripps MG, Edwards GR, Bourdôt GW, Saville DJ, Hinz HL, Fowler SV 2010. Effects of pasture competition and specialist herbivory on the performance of Cirsium arvense. Biocontrol Science and Technology 20: 641656. https://doi.org/10.1080/09583151003695407

Cripps MG, Gassmann A, Fowler SV, Bourdôt GW, McClay AS, Edwards GR 2011. Classical biological control of Cirsium arvense: Lessons from the past. Biological Control 57: 165-174. https://doi.org/10.1016/j. biocontrol.2011.03.011

Cripps MG 2013. Observations on the thistle-feeding tortoise beetle, Cassida rubiginosa (Coleoptera: Chrysomelidae). The Weta 45: 5-13. Cripps MG, Bourdôt GW, Fowler SV 2013. Sleeper thistles in New Zealand: status and biocontrol potential. New Zealand Plant Protection 66: 99-104. https://doi.org/10.30843/nzpp.2013.66.5715

Cripps MG, Jackman SD, Roquet C, van Koten C, Rostás M, Bourdôt GW, Susanna A 2016. Evolution of Specialization of Cassida rubiginosa on Cirsium arvense (Compositae,
Cardueae). Frontiers in Plant Science 7: 1261. https:// doi.org/10.3389/fpls.2016.01261

Cripps MG, Jackman SD, van Koten C 2019. Folivory impact of the biocontrol beetle, Cassida rubiginosa, on population growth of Cirsium arvense. BioControl 64: 91-101. https://doi.org/10.1007/s10526-018-09915-z

Dhileepan K, Setter SD, McFadyen RE 2000. Response of the weed Parthenium hysterophorus (Asteraceae) to defoliation by the introduced biocontrol agent Zygogramma bicolorata (Coleoptera: Chrysomelidae). Biological Control 19: 9-16. https://doi.org/10.1006/ bcon.2000.0847

Donald WW 1993. Root versus shoot measurements to evaluate recovery of Canada thistle (Cirsium arvense) after several years of control treatments. Canadian Journal of Plant Science 73: 369-373. https://doi. org/10.4141/cjps93-055

Edwards GR, Bourdôt GW, Crawley MJ 2000. Influence of herbivory, competition and soil fertility on the abundance of Cirsium arvense in acid grassland. Journal of Applied Ecology 37: 321-334. https://doi.org/10.1046/j.13652664.2000.00495.x

Goeden RD 1974. Comparative survey of the phytophagous insect faunas of Italian thistle Carduus pycnocephalus, in southern California and southern Europe relative to biological control. Environmental Entomology 3: 464474. https://doi.org/10.1093/ee/3.3.464

Groenteman R, Kelly D, Fowler SV, Bourdôt G 2008. Which species of thistle biocontrol agent Trichosirocalus are present in New Zealand? In: Julien M, Sforza R, Bon MC, Evans HC, Hatcher PEet al. Ed. Proceedings of the XII International Symposium on Biological Control of Weeds. La Grande Motte, France, CABI. Pp. 145-149. https://doi.org/10.1079/9781845935061.0145

Groves R, Sheppard AW 2012. Carduus pycnocephalus L. slender thistle Carduus tenuiflorus Curt. - slender thistle. In: Julien M, McFadyen R, Cullen J Ed. Biological Control of Weeds in Australia. Melbourne, CSIRO Publishing. Pp. 131-138.

Hettiarachchi D, Cripps M, Jackman S, Van Koten C, Sullivan J, Rostas M 2018. Impact of the biocontrol beetle, Cassida rubiginosa, on the secondary weed target, marsh thistle (Cirsium palustre). New Zealand Plant Protection 71: 6671. https://doi.org/10.30843/nzpp.2018.71.145

Jessep CT 1989. Introduction of the crown weevil (Trichosirocalus horridus) as an additional biocontrol agent against nodding thistle. Proceedings of the New Zealand Weed and Pest Control Conference 42: 52-54. https://doi.org/10.30843/nzpp.1989.42.10953

Kelly D, Popay AI 1985. Pasture production lost to unsprayed thistles at two sites. Proceedings of the New Zealand Weed and Pest Control Conference 38: 115-118. https:// doi.org/10.30843/nzpp.1985.38.9445

Kelly D 1988. Demography of Carduus pycnocephalus and $C$. tenuiflorus. New Zealand Natural Sciences 15: 17-24.

Kelly D, McCallum K, Schmidt CJ, Scanlan PM 1990. Seed predation in nodding and slender winged thistles by nodding thistle receptacle weevil. Proceedings of the New Zealand Weed and Pest Control Conference 43: 212215. https://doi.org/10.30843/nzpp.1990.43.10859 
Klinkhamer PGL, de Jong TJ, Meelis E 1987. Delay of flowering in the 'biennial' Cirsium vulgare: Size effects and devernalization. Oikos 49: 303-308. https://doi. org $/ 10.2307 / 3565765$

Olivieri I, Swan M, Gouyon P-H 1983. Reproductive system and colonizing strategy of two species of Carduus (Compositae). Oecologia 60: 114-117. https://doi. org/10.1007/BF00379329

Poorter H, Bühler J, van Dusschoten D, Climent J, Postma JA 2012. Pot size matters: a meta-analysis of the effects of rooting volume on plant growth. Functional Plant Biology 39: 839-850. https://doi.org/10.1071/ FP12049

Popay I, Champion P, James T 2010. An illustrated guide to common weeds of New Zealand. Third ed. Christchurch, New Zealand Plant Protection Society. 416 p.

SAS Institute Inc. 2012. https://www.sas.com/ (accessed 30 October 2020).

Webb CJ, Sykes WR, Garnock-Jones PJ 1988. Flora of New Zealand. Christchurch, DSIR, Botany Division. 1365 p.

Winston R, Schwarzländer M, Hinz HL, Day M, Cock M, Julien M 2014. Biological Control of Weeds: A World Catalogue of Agents and Their Target Weeds. 5th ed. Morgantown, West Virginia, USDA Forest Service. 838 p.

Zwölfer H, Eichhorn 0 1966. The host ranges of Cassida spp. (Col. Chrysomelidae) attacking Cynareae (Compositae) in Europe. Zeitchrift für Entomologie 58: 384-397. https://doi.org/10.1111/j.1439-0418.1966.tb04354.x 